\title{
Pollen mixture, a recombination alternative in common bean breeding
}

\author{
Fernanda Rausch Fernandes Carrijo'; Magno Antonio Patto Ramalho*i1; Ângela de Fátima \\ Barbosa Abreu ${ }^{2}$ and José Eustáquio de Souza Carneiro ${ }^{3}$
}

${ }^{1}$ Departamento de Biologia, UFLA, Caixa Postal 37, CEP 37200-000, Lavras, MG, Brazil; ${ }^{2}$ Embrapa Arroz e Feijão/ UFLA, Departamento de Biologia, UFLA, Caixa Postal 37, CEP 37200-000, Lavras, MG, Brazil; ${ }^{3}$ Departamento de Fitotecnia, UFV, CEP 36571-000, Viçosa, MG, Brazil. (* Corresponding Author. E-mail: magnoapr@ufla.br)

\begin{abstract}
Recombination can be a limiting factor in recurrent selection programs, especially in species such as common bean where artificial hybridization reduces seed setting. Therefore, the development of new techniques to improve recombination efficiency is important. Experiments were conducted in two sowing periods, July (autumn-winter season) and February (dry growing season), using the ESAL 686 and Small White cultivars as the female parents and the Carioca, Ouro Negro and ESAL 686 or Small White cultivars as male parents, depending on the female parent. Five technicians with different hybridization experience and two hybridization methods (with and without emasculation) were tested. A mixture of pollen from the three male parents was used in the pollinations, which were made in greenhouse. The resulting $F_{1}$ seeds were sown in the field and the male parent identified by morphological markers. The greatest pollination success $(68 \%)$ occurred in the autumnwinter season without emasculation. It was also observed that the technicians differed in efficiency, but no method $\mathrm{x}$ technician interaction was detected. The pollen mixture was efficient to improve recombination.
\end{abstract}

KEY WORDS: Phaseolus vulgaris L; genetic breeding, artificial pollination.

\section{INTRODUCTION}

Most of the traits of economic importance are controlled by poligenes (Basset, 1996; Singh, 2001). In breeding programs, therefore, a pair or a restricted number of parents carrying all favorable alleles should be identified to facilitate desirable allele combination into a single line. However, even when these parents are identified there is the further difficulty of handling thousands of individuals in the segregant populations to identify those carrying most of the required alleles. As this whole process is practically impossible, genetic breeding has to be performed in stages by the gradual accumulation of favorable alleles.

One of the alternatives for gradual breeding is the use of recurrent selection, which is characterized by continuous cycles of selection followed by recombination of the best individuals or families (Ramalho et al., 2001). Recurrent selection was originally proposed for cross-pollinating species but more recently it has been increasingly and successfully used in breeding of self-pollinating plants (Ranalli, 1996; Uphoft et al., 1997; Rangel et al., 1998).

A recurrent selection program basically involves three stages: forming base populations, selecting the best individuals and/or families and recombining them.
Especially in self-pollinating species, the last stage has to be carried out manually when male sterility is not available. In the specific case of the common bean, hybridization demands manual skill, is slow and produces a restricted number of seeds, three to four, in each successful operation. In most recurrent selection examples involving self-pollinating species, recombination is carried out using $\mathrm{S}_{0: 1}$ or $\mathrm{S}_{0: 2}$ families (Ramalho et al., 2001). As these types of families segregate, a large number of individuals must be used for good genetic representativeness. The consequence of these difficulties is imperfect recombination leading to a decrease in the method's efficiency.

An alternative is recombination by means of a mixture of pollen from different plant individuals. Information regarding viability of this practice was not found in the literature. The present study was carried out to identify the best hybridization strategies for common bean breeding, especially those useful in recurrent selection programs.

\section{MATERIAL AND METHODS}

The studies were set up in the experimental area of the Departamento de Biologia of the Universidade Federal de Lavras at the Lavras-MG county, located 
at $21^{\circ} 14^{\prime}$ South latitude and $45^{\circ} 00^{\prime}$ West longitude and $910 \mathrm{~m}$ altitude. The following common bean cultivars were used as parents: Small White (indeterminate growth habit, white flowers and white grains), ESAL 686 (determinate growth habit, pink flowers and yellow grains), Carioca (indeterminate growth habit, white flowers and cream colored grains with brown stripes) and Ouro Negro (indeterminate growth habit, violet flowers and black grains).

The $F_{1}$ seeds were obtained by artificial hybridizations using Small White and ESAL 686 as female parent. Small White was pollinated with a mixture of pollen from Carioca, Ouro Negro and ESAL 686, while ESAL 686 was pollinated with a mixture of pollen from Carioca, Ouro Negro and Small White. Stigmas of recently opened flowers carrying viable pollen on the surface were used (Vieira, 1967). Pollination was performed rubbing and placing three stigmas - one of each male parent, on the stigma of the flower used as female parent.

The pollinations were carried out in a greenhouse using five technicians and two methods, with emasculation (following the methodology of Ramalho et al., 1993) and without emasculation (Antunes et al., 1980), in the July/August 2000 and February/ March 2001 growing seasons. Sowings were scheduled over four consecutive weeks in both periods to promote cultivar flowering coincidence. Woolen threads of two different colors identified each technician and crossing methods (with and without emasculation). Technician and method could be identified at pod harvesting.

Sowing the seeds in rows in the field, according to technician, method and female parent, allowed identification of the pollen source of the $F_{1}$ seed. These rows were visited periodically to identify the male parent using hypocotyl, flower and grain colors and cross incompatibility as markers.

Data on percentage of successful hybridization between two cultivars were transformed $\sqrt{x+0.5}$ and submitted to analysis of variance (Steel et al., 1997). The number of hybrid seeds derived from each male and female cultivar combination was transformed to and submitted to analysis of variance by sowing period.

\section{RESULTS AND DISCUSSION}

Sowing the parental cultivars at regular time intervals allowed good coincidence of flowering. The average pollination success was greater than $57 \%$ (Table 1), which was far greater than the $30 \%$ mean percentage of successful pollinations normally obtained under natural conditions (Alves et al., 2001). This occurred because the artificial pollinations were carried out in a greenhouse, with good environmental control, especially water availability that, along with temperature, is fundamental to reduce flower abortion (Peternelli and Borém, 1999). Furthermore, the technicians sought to use the first flowers in the pollinations. Portes (1996) reported that the percentage of successful pollinations is greater in the first days of flowering. Additionally, it is common practice during artificial pollinations to make one or at most two pollinations per inflorescence, eliminating the other flowers. This procedure that reduces competition and increases pollination success does not happen under natural conditions.

Although one technician had less experience than the others, the pollination success did not differ significantly among them. This showed that although pollination requires some skill it can be learnt quickly. It is also pointed out that in spite of fact that the method of artificial hybridizations without emasculation had not been previously used by four out of the five technicians involved, it was more efficient than the method with emasculation. The average pollination success, regardless of the technician or sowing season, was $31.3 \%$ greater in the method without emasculation than in the method with emasculation (Table 1). This clearly indicated that hand pollination without emasculation should be more widely used, especially due to its simplicity. Emasculation demands skill and time.

July sowings, carried out for the autumn-winter season, resulted in $68.3 \%$ successful pollinations. This percentage was superior to that obtained in the February sowings (46\%) for the dry season sown (Table 1). Considering that the pollinations were carried out in pots in a greenhouse, the main environmental difference between the two seasons was temperature. This finding was corroborated by the results obtained by Andrade (1998), who reported that the pollination success is sharply reduced under high temperature conditions, especially night temperatures.

As already mentioned, phenotypic markers were used to identify the percentage of self-pollination and the male parent of the hybrid seed. One marker was the occurrence of $F_{1}$ plants with abnormal development due to cross incompatibility (Vieira et al., 1999). Two genes $\left(\mathrm{Dl}_{1} \mathrm{Dl}_{2}\right)$ are involved in the genetic control of the phenomenon and there is double recessive 
epistatic interaction (Singh and Gutierrez, 1984). That is, when the dominant alleles of the two genes are present, the $\mathrm{F}_{1}$ plants do not develop. This occurred in all cases where the male parent was the Carioca cultivar $\left(\mathrm{Dl}_{1} \mathrm{Dl}_{1} \mathrm{dl}_{2} \mathrm{dl}_{2}\right)$ and the female parent was the ESAL $686\left(\mathrm{dl}_{1} \mathrm{dl}_{1} \mathrm{Dl}_{2} \mathrm{Dl}_{2}\right)$. Incompatibility was not expressed in the crosses involving the Small White cultivar, because its constitution is $\mathrm{dl}_{1} \mathrm{dl}_{1} \mathrm{dl}_{2} \mathrm{dl}_{2}$. Similarly, incompatibility also was not expressed in crosses involving the Ouro Negro cultivar.

Hypocotyl and flower color were other marker traits. Some of the genes involved in the control of hypocotyl and flower color are pleiotropic, that is, they simultaneously affect both traits. One of the genes involved is the $\mathrm{P}$ gene with two alleles $(\mathrm{P}>\mathrm{p})$. The dominant $P$ allele is essential for color expression. The other gene is the $\mathrm{V}$ gene with three alleles $\left(\mathrm{V}>\mathrm{V}^{\text {lae }}>\mathrm{V}\right)$, which is only expressed in the presence of the P allele (Singh, 1991; Basset, 1996). The studied cultivars have the following genotypes: Small White is ppVV, that is, it has green hypocotyl and white flowers; Carioca is PPvv, presenting green hypocotyl and white flowers; Ouro Negro is PPVV, having purple hypocotyl and violet flowers; ESAL 686 is $\mathrm{PPv}^{\text {lae }} \mathrm{v}^{\text {lae }}$, presenting green hypocotyl and pink flowers due to the $\mathrm{v}^{\text {lae }}$ allele.

Unfortunately, the flower and hypocotyl color markers that are easy to see were not very useful in this study because the hybrid plants had purple hypocotyl and violet flowers regardless of the male or female parent. These markers, however, allowed identification of the self-pollinations that presented white or pink flowers, respectively, for the Small White and ESAL 686 parents. As already mentioned, flower color was violet in the hybrids.

On the other hand, grain color, which was the other phenotypic marker used, confirmed the occurrence of self-pollination when the grain type was similar to that of the female parent and allowed identification of the male parent in the hybrids. Crosses involving the Ouro Negro cultivar as male parent resulted in black grain color independent of the female parent, while crosses involving the Carioca cultivar as male parent resulted in beige with brown stripes grains when the female parent was the Small White cultivar. As already mentioned, plants derived from the Carioca x ESAL 686 cross were incompatible and did not produce seeds. The $\mathrm{F}_{1}$ generation of the ESAL $686 \times$ Small White cross had striped seeds very different from the others regardless of the female parent. Therefore, the origin of the $\mathrm{F}_{1}$ seeds could be traced.

Table 2 shows the analysis of variance of the number of hybrid seeds according to each male parent. The interactions were significant. The greatest discrepancy occurred regarding the parent effect, which was significant only in the case of the Small White cultivar used as female parent.

Data on number of self-pollinated seeds were not included in the analyses of variance, but their means were presented along with the number of $F_{1}$ hybrid seeds from each male parent (Table 3). It is worth noting that the numbers of self-pollinated seeds were always smaller than that of hybrid seeds. In the mean of the two growing seasons, the self-pollinations corresponded to $5.5 \%$ and $3.5 \%$ of all produced seeds for ESAL 686 and Small White used as female parents, respectively. Although the difference between the female parents was not large, the fact that self-pollination was greater in the ESAL 686 cultivar was not expected because it has larger flowers than Small White. Large flowers facilitate handling and decrease the chances of self-pollination.

The self-pollination percentage results showed the importance of using markers to identify the possible self-pollinations. This care is especially important in artificial common bean hybridization carried out for genetic control studies or for other purposes that

Table 1. Average successful pollination (\%) in the female parents obtained by the five technicians in the two sowing seasons and two hybridization methods. Lavras, 2001.

\begin{tabular}{|c|c|c|c|c|c|c|c|}
\hline \multirow{3}{*}{ Technicians } & \multicolumn{3}{|c|}{ Sowing in July/2000 } & \multicolumn{3}{|c|}{ Sowing in February/2001 } & \multirow{3}{*}{ Mean } \\
\hline & \multicolumn{2}{|c|}{ Emasculation } & \multirow[b]{2}{*}{ Mean } & \multicolumn{2}{|c|}{ Emasculation } & \multirow[b]{2}{*}{ Mean } & \\
\hline & without & with & & Without & with & & \\
\hline $\mathrm{A}$ & 86.84 & 75.61 & 81.23 & 64.45 & 57.50 & 60.98 & 71.11 \\
\hline B & 85.00 & 54.55 & 69.78 & 59.02 & 41.89 & 50.46 & 60.12 \\
\hline $\mathrm{C}$ & 68.75 & 77.78 & 73.27 & 65.52 & 14.14 & 39.83 & 56.55 \\
\hline $\mathrm{D}$ & 75.00 & 47.62 & 61.31 & 49.17 & 32.20 & 40.69 & 51.00 \\
\hline $\mathrm{E}$ & 54.26 & 57.89 & 56.08 & 42.11 & 34.23 & 38.17 & 47.13 \\
\hline Mean & 73.97 & 62.69 & 68.33 & 56.05 & 35.99 & 46.03 & 57.18 \\
\hline
\end{tabular}


require assurance that hybrid seeds were obtained. There are many markers that can be used.

The most expressive result, however, was the possibility of carrying out pollinations using a mixture of pollens. The proportion of hybrid seeds obtained from each male parent was very similar (Tables 3 and 4). In the analysis of variance, the pollen origin $x$ technician interaction was not significant (Table 2), showing that the previous observation is valid regardless of the technician. Also, in spite of significant seasonal differences in terms of the relative quantity of hybrid seeds produced, the results of the two seasons for the two female parents were very similar (Table 4).

These results show that recombination in common bean recurrent selection programs, or while obtaining segregant populations derived from multiple crosses, can be performed using a mixture of pollen. Considering that the pollination technique involved the stigma of recently opened flowers, where viable pollen was available (Vieira, 1967), stigmas of three or even more plants can be simultaneously used. Therefore, as was observed in the study, the number of plants involved in the pollinations can be increased and consequently, the recombination should be further improved.

Table 2. Summary of the analyses of variance of hybrid seed number (data transformed to $\sqrt{x+0.5}$ ) for the two hybridization seasons with both cultivars used as female parent. Lavras, 2001.

\begin{tabular}{|c|c|c|c|c|c|}
\hline \multirow{3}{*}{ Variation Sources } & \multirow{3}{*}{ DF } & \multicolumn{4}{|c|}{ MS } \\
\hline & & \multicolumn{2}{|c|}{ 오 ESAL 686} & \multicolumn{2}{|c|}{ of Small White } \\
\hline & & $1^{\text {st }}$ season & $2^{\text {st }}$ season & $1^{\text {st }}$ season & $2^{\text {st }}$ season \\
\hline Methods (M) & 1 & 2.63 & $10.40 * *$ & $32.87 * *$ & $7.65^{*}$ \\
\hline Parents (P) & 2 & 0.32 & 0.29 & $7.00 * *$ & $5.94 *$ \\
\hline Technicians (T) & 4 & $9.26 * *$ & $2.11 * *$ & $11.77 * *$ & 2.54 \\
\hline $\mathrm{M} \times \mathrm{P}$ & 2 & 0.62 & 2.09 & 0.49 & 0.25 \\
\hline $\mathrm{Mx} \mathrm{T}$ & 4 & 4.06 & 0.07 & 2.14 & 0.65 \\
\hline $\mathrm{P} \times \mathrm{T}$ & 8 & 0.88 & 0.63 & 0.29 & 1.00 \\
\hline Experimental error & 8 & 1.22 & 0.35 & 0.78 & 0.97 \\
\hline V.C. $(\%)$ & & 29.10 & 20.00 & 24.50 & 40.10 \\
\hline
\end{tabular}

Table 3. Total number and percentage of hybrid seeds obtained by each one of the technicians for each female and male parent, regardless of the sowing season and hybridization method. Lavras, 2001.

\begin{tabular}{|c|c|c|c|c|c|c|}
\hline \multirow[b]{3}{*}{ Pollen source } & \multicolumn{5}{|c|}{ ㅇ ESAL 686} & \multirow[b]{3}{*}{ Mean $(\%)$} \\
\hline & \multicolumn{5}{|c|}{ Technicians } & \\
\hline & $\mathrm{A}$ & $\mathrm{B}$ & $\mathrm{C}$ & $\mathrm{D}$ & $\mathrm{E}$ & \\
\hline Carioca & $68(35.24)^{1 /}$ & $54(35.53)$ & $28(39.44)$ & $79(29.59)$ & $34(26.15)$ & 33.19 \\
\hline Ouro Negro & $66(34.20)$ & $39(25.66)$ & $23(32.39)$ & $91(34.08)$ & $37(28.46)$ & 30.96 \\
\hline Small White & $58(30.06)$ & $46(30.26)$ & $16(22.54)$ & $94(35.21)$ & $44(33.85)$ & 30.38 \\
\hline Self-pollination & $1(0.50)$ & $13(8.55)$ & $4(5.63)$ & $3(1.12)$ & $15(11.54)$ & 5.47 \\
\hline \multirow[t]{3}{*}{ Total } & $193(100)$ & $152(100)$ & $71(100)$ & $267(100)$ & $130(100)$ & \\
\hline & \multicolumn{5}{|c|}{ OSMALL WHITE } & \\
\hline & \multicolumn{5}{|c|}{ Technicians } & \\
\hline Pollen source & $\mathrm{A}$ & $\mathrm{B}$ & $\mathrm{C}$ & $\mathrm{D}$ & $E$ & $\operatorname{Mean}(\%)$ \\
\hline Carioca & $89(45.18)$ & $78(48.75)$ & $28(38.88)$ & $77(38.31)$ & $33(38.82)$ & 41.99 \\
\hline Ouro Negro & $60(30.46)$ & $57(35.62)$ & $29(40.28)$ & $88(43.78)$ & $45(52.94)$ & 40.62 \\
\hline ESAL 686 & $48(24.36)$ & $23(14.38)$ & $4(5.56)$ & $36(17.91)$ & $6(7.06)$ & 13.85 \\
\hline Self-pollination & $0(0.00)$ & $2(1.25)$ & $11(15.28)$ & $0(0.00)$ & $1(1.18)$ & 3.54 \\
\hline Total & $197(100)$ & $160(100)$ & $72(100)$ & $201(100)$ & $85(100)$ & \\
\hline
\end{tabular}

\footnotetext{
${ }^{1 /}$ Number in brackets corresponds the mean percentage per technician.
} 
Table 4. Number and percentage of hybrid seeds from each male parent, regardless of the technician and the hybridization method, obtained in each sowing period when the ESAL 686 and Small White cultivars were used as female parents. Lavras, 2001.

\begin{tabular}{|c|c|c|c|}
\hline \multirow[b]{3}{*}{ Pollen source } & \multicolumn{2}{|c|}{ +9ESAL 686} & \multirow[b]{3}{*}{ Mean $(\%)$} \\
\hline & \multicolumn{2}{|c|}{ Sowing season } & \\
\hline & $1^{\text {st }}$ season & $2^{\text {st }}$ season & \\
\hline Carioca & $155(30.45)$ & $108(35.53)$ & $131.5(32.99)$ \\
\hline Ouro Negro & $161(31.63)$ & $95(31.25)$ & $128.0(31.44)$ \\
\hline Small White & $176(34.58)$ & $82(26.97)$ & $129.0(30.78)$ \\
\hline Self-pollination & $17(3.34)$ & $19(6.25)$ & $18.0(4.79)$ \\
\hline \multirow[t]{3}{*}{ Total } & $509(100)$ & $304(100)$ & \\
\hline & \multicolumn{2}{|c|}{ o Small White } & \\
\hline & \multicolumn{2}{|c|}{ Sowing season } & \\
\hline Pollen source & $1^{\text {st }}$ season & $2^{\text {st }}$ season & Mean $(\%)$ \\
\hline Carioca & $207(41.4 \%)$ & $98(45.58)$ & $152.5(43.49)$ \\
\hline Ouro Negro & $190(38 \%)$ & $89(41.40)$ & $139.5(39.70)$ \\
\hline ESAL 686 & $89(17.8 \%)$ & $28(13.02)$ & $58.5(15.41)$ \\
\hline Self-pollination & $14(2.8 \%)$ & $0(0.00)$ & $7.0(1.40)$ \\
\hline Total & $500(100)$ & $215(100)$ & \\
\hline
\end{tabular}

\section{RESUMO}

\section{Mistura de pólens como alternativa para a recombinação na cultura do feijoeiro}

Na condução de programas de seleção recorrente, a recombinação pode ser limitante, especialmente em espécies como o feijoeiro, em que na hibridação artificial é obtido número reduzido de sementes. Por isso, é importante o desenvolvimento de novas técnicas que visem tornar mais eficiente a etapa de recombinação. Com essa finalidade foram conduzidos experimentos em duas épocas de semeadura, em julho - cultura de outono-inverno, e fevereiro - "seca", utilizando duas cultivares como genitor feminino, ESAL 686 e Small White; e três como genitor masculino: Carioca, Ouro Negro e ESAL 686 ou Small White, dependendo do genitor feminino; cinco operadores diferindo em experiência na hibridação e dois métodos de hibridação, com e sem emasculação. Nas polinizações realizadas em casa-de-vegetação, utilizou-se a mistura de pólens dos três genitores. A percentagem de vingamento floral foi obtida para cada situação. Posteriormente, as sementes $F_{1}$ foram semeadas a campo, e, por meio de marcadores morfológicos, identificado o genitor masculino. Constatou-se que o maior vingamento floral $(68 \%)$ ocorreu na cultura do outono-inverno, no método sem emasculação. Observou-se também que os operadores diferiram em eficiência, porém não se constatou interação métodos x operadores. A mistura de pólens mostrou-se eficiente e deve ser utilizada visando à maior eficiência na recombinação.

\section{REFERENCES}

Alves, G.F.; Ramalho, M.A.P. and Abreu, A. de F.B. 2001. Desempenho de cultivares antigas e modernas de feijão avaliadas em diferentes condições ambientais. Revista Ciência e Agrotecnologia. 25:863-870.

Andrade, M.J.B. de. 1998. Clima e solo. p.83-97. In: Vieira, C.; Paula Júnior, T.J. de and Borém, A. (Eds.) Feijão: Aspectos gerais e cultura no estado de Minas. Ed. UFV, Viçosa.

Antunes, I.F.; Teixeira, M.G and Zimmermann, M.J. de O. 1980. Relative performance among crossing technique under field and greenhouse conditions on beans. Annual Report of the Bean Improvement Cooperative. 23:117-119.

Basset, M.J. 1996. List of genes. Annual Report of the Bean Improvement Cooperative. Fort Colins Colorado. 39:1-9.

Peternelli, L.A. and Borém, A. 1999. Hibridação em feijão. p.269-294. In: Borém, A. (Ed.) Hibridação artificial de plantas. Ed. UFV, Viçosa.

Portes, T.A. 1996. Ecofisiologia. p.101-137. In: Araújo, R.S.; Rava, C.A.; Stone, L.F. and Zimmermann, M.J. de O. (Eds.) Cultura do feijoeiro 
comum no Brasil. Potafós, Piracicaba.

Ramalho, M.A.P.; Abreu, A. de F.B. and Santos, J.B. dos. 2001. Melhoramento de espécies autógamas. p.201-230. In: Nass, L.L.; Valois, A.C.C.; Melo, I.S. de and Valadares-Inglis, M.C. (Eds.) Recursos genéticos e melhoramento - plantas. Ed. Fundação MT, Rondonópolis.

Ramalho, M.A.P.; Santos, J.B. dos and Zimmermann, M.J. de O. 1993. Genética quantitativa aplicada ao melhoramento de plantas autógamas: aplicações ao melhoramento do feijoeiro. Editora da UFG, Goiânia.

Ranalli, P. 1996. Phenotypic recurrent selection in common bean (Phaseolus vulgaris L.) based on performance of $\mathrm{S}_{2}$ progenies. Euphytica. 87:127-132.

Rangel, P.H.N.; Zimmermann, F.J.P. and Neves, P.C.F. 1998. Estimativas de parâmetros genéticos e resposta à seleção nas populações de arroz irrigado CNA - IRAT 4 PR e CNA - IRAT 4 ME. Pesquisa Agropecuária Brasileira. 33:905-912.

Singh, S.P. 1991. Bean genetics. p.199-286. In: Schoonhoven, A. van and Voysest, O. (Eds.) Common beans: research for crop improvement. Ed. CIAT, Cali.

Singh, S.P. 2001. Broadening the genetic base of common bean cultivars: a review. Crop Science. 41:1659-1675.

Singh, S.P. and Gutierrez, J.A. 1984. Geographical distribution of the $\mathrm{DL}_{1}$ and $\mathrm{DL}_{2}$ genes causing hybrid dwarfism in Phaseolus vulgaris L., their association with seed size, and their significance to breeding. Euphytica. 33:337-345.

Steel, R.G.D.; Torrie, J.H. and Dickey, D.A. 1997. Principles and procedures of statistics: a biometrical approach. McGraw-Hill, New York.

Uphoff, M.D.; Fehr, W.R. and Cianzio, S.R. 1997. Genetic gain for soybean seed yield by three recurrent selection methods. Crop Science. 37:1155-1158.

Vieira, C. 1967. O feijoeiro comum: cultura, doenças e melhoramento. Imprensa Universitária, Viçosa.

Vieira, C.; Borém, A. and Ramalho, M.A.P. 1999. Melhoramento do feijoeiro. p.273-349. In: Borém (Ed.) Melhoramento de espécies cultivadas. Ed. UFV, Viçosa.
Received: March 18, 2002;

Accepted: October 25, 2002. 